Journal of Extension Education

Vol. 28 No. 4, 2016

DOI:https: //doi.org/10.26725/JEE.2016.4.28.5740-5746

\title{
Adoption of Improved Strain of Backyard Poultry
}

\author{
P. Athilakshmi ${ }^{1}$ and S.V.N. Rao ${ }^{2}$
}

\begin{abstract}
Backyard poultry plays a major role in alleviating malnutrition in developing countries like India. The present study was undertaken among 120 backyard poultry farmers in Karaikal region of Puducherry an aim to assess the extent of adoption of improved strain of backyard poultry in Karaikal region, a backward area in Puducherry Union Territory. Majority of the respondents were middle aged with primary school level of education belonging to small family group with 6-15 years of experience in backyard poultry rearing. Nearly one third of the respondents had 1-5 birds in their backyard. Majority of the farmers reared desi birds followed by Giriraja strain. The average number of eggs per clutch and the average number of clutches per year were 16 and 6 respectively. Majority of the respondents were aware of the improved strains of backyard poultry. Most of them had discontinued rearing improved strain of backyard poultry mainly due to susceptibility to diseases and attack by predators.
\end{abstract}

Keywords: Backyard poultry, Adoption, Ranikhet disease, Giriraja strain, Puducherry, India

\section{INTRODUCTION}

Indian poultry sector is mostly organized and holds an important place in the country's GDP growth. Though the backyard poultry (BYP) population has dropped to 10 per cent in the total poultry population, it still plays a major role in rural household food security and income Generation. The government of India is also supporting rural backyard poultry production by introducing improved strains of backyard poultry viz.,
Vanaraja, Giriraja Krishibro, Krishilayer, CARIBRO, Gramapriya, Naked neck broiler, Dwarf broiler etc. The backyard poultry farmers, however, are facing lot of challenges in rearing these improved strains of BYP in their backyard. Thus, training is essential for these backyard poultry farmers in the fields like disease control, feeding, brooding, housing, breeding and marketing to successfully rear these improved strain of birds in their backyard.

1. Asst. Professor, Dept. of Veterinary and Animal Husbandry Extension, Madras Veterinary College, Chennai - 600007 and 2. Professor and Head (Retd.) Dept of Veterinary and Animal Husbandry Extension, Rajiv Gandhi Institute of Veterinary Education and Research, Puducherry 
Hitherto, the potential of backyard poultry (BYP) in Puducherry has been unexplored by the researchers even in Karaikal region which ranks first in the backyard poultry population among the four regions of Puducherry Union Territory (U.T.). Keeping this in mind, a study was undertaken among 120 backyard poultry farmers in Karaikal region of Puducherry with an aim to assess the extent of adoption of improved strain of backyard poultry in Karaikal region, a backward area in Puducherry U.T.

\section{METHODOLOGY}

Karaikal was purposively selected to conduct the study since it ranked first in backyard poultry population among the four regions of Puducherry Union Territory. Altogether, 120 respondents were selected from the two communes namely Nedungadu and Thirunallar to study the socio economic profile of the backyard poultry farmers. From each commune, three villages were selected at random. A list of backyard poultry farmers was prepared for each of the six selected villages. From this list, 20 farmers from each village were selected randomly. Thus, the sample size included 120 respondents drawn from six villages representing two communes to study the socio economic profile of the backyard poultry farmers.

\section{FINDINGS AND DISCUSSION}

\section{Profile of the BYP Farmers}

The profile of the 120 backyard poultry farmers in terms of their age, gender, education, family size, type of house, religion and caste was assessed. Almost half of the respondents belonged to middle age group. Nearly one third were young and the rest belonged to old age group. About per cent of the respondents had only primary level of education. Those who had secondary and higher secondary level of education were 24 per cent and 9 per cent respectively. There were about 10 per cent of the respondents who were illiterate.

Nearly 60 per cent of the respondents belonged to small family with less than or equal to four members. The respondents in medium and large family categories were 35 per cent and 5.8 per cent respectively. This showed that small family norm is being practiced even in rural areas.

\section{Experience in Poultry Rearing}

About 45 per cent of the respondents had more than 15 years of experience in backyard poultry rearing. Barring about a quarter of respondents, the rest had an experience of at least six years in rearing backyard poultry.

\section{Flock Size}

Nearly one third of the respondents had less than six birds in their backyard. The number of respondents with 6-10 birds and 11-20 birds in their backyard were nearly equal (25\% each). 


\section{Number of Birds Reared}

Majority of the respondents (109 families) were rearing native birds at their backyard. The average number of native birds reared per family was 10.7. In addition to native birds few respondents were rearing birds such as Giriraja birds (26), Leghorn birds (14) and Aseel birds (9) The results are presented in Table1.

Table 1.

Number of Birds Reared

\begin{tabular}{|c|l|c|r|c|}
\hline S1. No. & \multicolumn{1}{|c|}{ Type } & $\begin{array}{c}\text { No.of families } \\
\text { rearing * }\end{array}$ & Total & $\begin{array}{c}\text { Average no. of birds } \\
\text { per family }\end{array}$ \\
\hline 1. & Native birds & 109 & 1171 & 10.7 \\
\hline 2. & Giriraja birds & 26 & 192 & 7.3 \\
\hline 3. & Leghorn birds & 14 & 86 & 6.1 \\
\hline 4. & Aseel birds & 9 & 96 & 10.7 \\
\hline
\end{tabular}

*Multiple responses

Categorization of the Respondents Based on the Number of Eggs per Clutch

The number of eggs laid per clutch by the birds was between 11 and 20 eggs in about 87 per cent of the respondents' houses. The average number of eggs laid per clutch by the birds was 15.8 .

\section{Categorization of the Respondents Based on the Number of Clutches per year}

The number of clutches per year ranged from 3-8 for desi birds in the study area. A little more than half of the respondents indicated that on an average their birds had 5 or 6 clutches per year. The clutches per bird per year was more in study area because the respondents were following the peculiar practice of

selecting one bird for brooding keeping other birds for laying purpose. When other birds start brooding, the respondents dip the birds in cold water to bring them out of brooding stage.

\section{Adoption of Improved Strain of BYP}

The respondents were categorised into adopters, discontinued and non adopters of improved strain of BYP based on Rogers' (2003) classification. The findings pertaining to the adoption of improved strain of backyard poultry by the respondents, its discontinuance and rejection are presented below:

\section{a) Rearing Improved Strain of BYP}

Although 80 per cent of the respondents were aware of the improved 
strain of backyard poultry (Table 2), only about 27 per cent of them reared improved strain of backyard poultry at the time of study and hence were categorised as adopters. The number of the respondents who discontinued was 46 whereas, the non adopters who were aware of the improved strain of backyard poultry but rejected it were 24 .

Table 2.

Adoption of Improved Strain of BYP

\begin{tabular}{|c|l|c|c|c|}
\hline $\begin{array}{c}\text { S1. } \\
\text { No. }\end{array}$ & \multicolumn{1}{|c|}{ Contents } & f & \% & N \\
\hline 1. & No.of Respondents aware of improved Strains of BYP & 96 & 80.0 & 120 \\
\hline 2. & No.of Respondents adopting at present & 26 & 27.1 & 96 \\
\hline 3. & No.of Respondents discontinued & 46 & 47.9 & 96 \\
\hline 4. & No.of non adopters & 24 & 25.0 & 96 \\
\hline
\end{tabular}

Table 3.

Adoption Chracteristics of Improved Strain of BYP

\begin{tabular}{|c|c|c|c|c|}
\hline S1. No. & Contents & $\mathbf{f}$ & $\%$ & $\mathbf{N}$ \\
\hline 1. & Rearing improved strain of BYP at present & 26 & 27.1 & 96 \\
\hline 2 . & Strain - Giriraja & 26 & 100.0 & 26 \\
\hline 3. & $\begin{array}{l}\text { Age at purchase of chicks } \\
\text { a) } 4 \text { weeks } \\
\text { b) } 8 \text { weeks } \\
\text { c) } 24 \text { weeks } \\
\text { d) Fertile eggs }\end{array}$ & $\begin{array}{l}15 \\
09 \\
01 \\
01\end{array}$ & $\begin{array}{r}57.6 \\
34.6 \\
3.9 \\
3.9\end{array}$ & 26 \\
\hline 4. & $\begin{array}{l}\text { Source } \\
\text { a) Vendor } \\
\text { b) Dispensary } \\
\text { c) Neighbours/relatives } \\
\text { d) Farm }\end{array}$ & $\begin{array}{l}12 \\
08 \\
05 \\
01\end{array}$ & $\begin{array}{r}46.2 \\
30.7 \\
19.2 \\
3.9\end{array}$ & 26 \\
\hline
\end{tabular}


The figures in the table reveal that out of 96 respondents who were aware of the improved strain, only 26 were found adopting improved strain (Giriraja). This was the strain being distributed by the Department of Animal Husbandry as well as sold by vendors in these villages. More than half of the respondents (57.6\%) purchased these birds at four weeks of age. About 35 per cent of the respondents purchased these birds at 8 weeks of age. The study also revealed that none of the respondents purchased day old chicks of any improved strain including Giriraja.
These results indicate that the improved strains of BYP were not popular among the respondents.

\section{b. Reasons for Adoption of Improved Strain of BYP}

The major reason expressed by the respondents (65.3\%) for rearing improved strain of birds was the requirement of eggs for home consumption, whereas 23.1 per cent of the respondents were rearing them for income purpose (Table.4). Very few respondents were rearing these birds as a hobby.

Table 4.

Reasons for Adoption of Improved Strain of BYP

\begin{tabular}{|c|c|c|c|c|}
\hline S1. No. & Contents & f & \% & N \\
\hline 1. & No.of Respondents adopting at present & 26 & 27.1 & 96 \\
\hline 2. & Reasons for adoption & & & \\
& i) Eggs for household consumption. & 17 & 65.4 & \\
& ii) Income & 06 & 23.1 & 26 \\
& iii) Colour of plumage & 03 & 11.5 & \\
\hline
\end{tabular}

\section{c. Reasons for Discontinuing Improved Strain of BYP}

Nearly half of the respondents (47.9\%) had discontinued the practice of rearing improved strain of backyard poultry for several reasons (Table.5). The important reasons for discontinuing were disease outbreak (32.6\%) and predators (26.1\%). There were 10 respondents who could not get chicks again for rearing after they slaughtered and used the birds for home consumption. Apart from these, most of the respondents did not develop bond with these birds since they got these birds at an age of more than six weeks and they reared them basically for meat purpose rather than allowing them to grow upto egg laying stage. 
Adoption of Improved Strain of Backyard Poultry

Table 5.

Reasons for Discontinuing Improved Strain of BYP

\begin{tabular}{|c|l|c|c|c|}
\hline S1. No. & \multicolumn{1}{|c|}{ Contents } & f & \% & N \\
\hline 1. & No.of Respondents discontinued & 46 & 47.9 & 96 \\
\hline 2. & \multicolumn{1}{|c|}{ Reasons for discontinuing } & & & \\
& i) Susceptibility to Disease & 15 & 32.6 & \\
& ii) Predators & 12 & 26.1 & \\
& iii) Slaughtered \& consumed & 4 & 21.7 & 46 \\
& iv) Difficult to rear & 5 & 10.9 & \\
& v) Non availability of chicks & & \\
\end{tabular}

\section{d. Reasons for Non Adoption of Improved Strain of BYP}

It could be inferred from the table that 25 per cent of the respondents though aware of the improved strain of backyard poultry did not adopt it for various reasons. One third of them (33.3\%) did not adopt because of disease outbreaks. Some of the respondents (25\%) expressed the difficulty in rearing the improved strain of birds which need special care and protection from predators.

Table 6.

Reasons for Non adoption of Improved Strain of BYP

\begin{tabular}{|c|l|l|l|l|}
\hline S1. No. & \multicolumn{1}{|c|}{ Contents } & f & \multicolumn{1}{c|}{$\%$} & N \\
\hline 1. & No.of non adopters & 24 & 25.0 & 96 \\
\hline 2. & \multicolumn{1}{|c|}{ Reasons for non adoption } & 8 & 33.3 & \\
& i) Susceptibility to Disease & 6 & 25.0 & \\
& ii) Difficult to rear & 4 & 16.7 & 24 \\
& iii) No interest & 3 & 12.5 & \\
& iv) Non availability of chicks & 3 & 12.5 & \\
\hline
\end{tabular}




\section{CONCLUSION}

Almost all the respondents were aware of the improved strains of backyard poultry and had experience of rearing Giriraja chicks purchased mostly from vendors and veterinary dispensaries at the age of 6 weeks. Most of the 120 respondents disposed Giriraja birds at a very young age without allowing them to reach egg laying stage probably due to lack of their attachment to the birds.

Except few, most of them had discontinued rearing improved strain of backyard poultry mainly due to their susceptibility to diseases and attack by predators.

Therefore, the animal husbandry sector should not only stop with supply of hybrid strain of birds but it also should aid the supportive services like vaccination, feeding, housing, marketing of these birds in order to encourage backyard poultry farmers. Thus, the extension activities should be intensified to efficiently transfer the technology from the lab to the farmer's doorstep.

\section{REFERENCES}

Mandal, M. K., Khandekar, N. \& Khandekar, P. (2006). Backyard poultry farming in Bareilly district of Uttar Pradesh, India: an analysis, Livestock Research for Rural Development, 18 (7).

Rogers E.M. (2003). Diffusion of Innovations. Free Press, New York. 